\title{
PEMBELAJARAN DARING DAN KONSEKUENSINYA PADA KESEPIAN SISWA: TINJAUAN LITERATUR
}

\author{
Ani Cahyadi \\ Universitas Islam Negeri (UIN) Antasari, Banjarmasin, Indonesia \\ e-mail: anicahyadi@uin-antasari.ac.id
}

Agus Setiawan

Universitas Islam Negeri Sultan Aji Muhammad Idris (UINSI) Samarinda, Indonesia e-mail: agus.setiawan@iain-samarinda.ac.id

\begin{abstract}
Abstrak
Sebagai upaya untuk menghentikan penyebaran dan penularan COVID-19, seluruh aktivitas pembelajaran dipindahkan ke mode daring. Praktek ini telah disebut social distancing yang mengharuskan orang untuk terpisah secara fisik. Keharusan ini merupakan bentuk pemisahan yang dapat memicu perasaan terisolasi yang selanjutnya berkontribusi pada tingkat kesepian yang belum pernah terjadi sebelumnya. Artikel ini bertujuan untuk mengeksplorasi apakah pembelajaran daring memiliki potensi negative bagi siswa karena tidak efektifnya komunikasi antara pengajar dan siswa. Meskipun teknologi menawarkan banyak kemudahan dan kesempatan yang lebih besar bagi siswa untuk mengakses pembelajaran kapan saja dan dimana saja, namun sisi lainnya dapat menjadi pemicu rasa kesepian siswa karena kurangnya interaksi fisik dengan guru dan rekan sejawatnya. Suasana belajar online yang jauh dan impersonal juga dapat mendorong siswa tidak mengenal satu sama lain, dan kondisi ini kurang baik untuk perkembangan psikologis siswa.
\end{abstract}

Kata kunci-pembelajaran daring, kesepian siswa

\section{PENDAHULUAN}

Pandemi COVID-19 terjadi sejak awal tahun 2020 menyebabkan administrator pendidian memindahkan pembelajaran tatap muka ke lingkungan online untuk mencegah penularan virus yang lebih luas. Ada banyak tantangan yang dihadapi oleh para pendidik di Indonesia dalam emergency remote teaching (ERT) yang dilaksanakan selama hampir dua tahun terakhir ini. Seperti halnya negara lain yang banyak menemui kendala pada aktivitas remote teaching (misalnya masalah akses internet, penyesuaian materi), problem yang terjadi pada pembelajaran yang menggunakan media online jauh lebih kompleks. Diluar masalah konektivitas dan hambatan teknologi, muncul juga tren peningkatan perilaku tidak sopan di kelas online ${ }^{1}$. Terbatasnya interaksi social secara langsung menyebabkan hambatan komunikasi interpersonal yang kemudian memicu komentar dan perilaku tidak sopan yang dilakukan oleh siswa.

Hambatan utama dalam pembelajaran daring adalah komunikasi yang sering kali tidak

${ }^{1}$ Spadafora, N., \& Volk, A. A. (2021). Child and Youth Classroom Incivility Scale (CYCIS): exploring uncivil behaviors in the classroom. School mental health, 13(1), 186-200. 
Ani Cahyadi, Agus Setiawan : Pembelajaran Daring dan Konsekuensinya Pada Kesepian Siswa : Tinjauan Literatur

efektif. Berkomunikasi dengan siswa di lingkungan online membutuhkan sedikit lebih banyak pemikiran dan perencanaan daripada berkomunikasi dengan siswa di lingkungan tradisional karena lingkungan online tidak memiliki bahasa tubuh. Guru dikelas mungkin memiliki keuntungan dengan menggunakan bahasa tubuh dan ekspresi wajah di kelas tatap muka sehingga membantu mereka terhubung kepada siswa di kelas. Saat berinteraksi di kelas online, guru tidak memiliki keuntungan menggunakan bahasa tubuh untuk membantu siswa mereka berkomunikasi ${ }^{2}$. Meskipun kelas daring dapat mengaktifkan video sehingga guru dan siswa dapat melihat satu sama lain, namun hal ini membutuhkan akses Internet cepat dan random access memory (RAM) yang tinggi pada perangkat seluler akan menimbulkan masalah baru, seperti terhambatnya proses pembelajaran dan peningkatan konsumsi kuota dengan cepat. ${ }^{3}$ Akibatnya, banyak masalah teknis dapat terjadi dalam konferensi video, seperti kehilangan suara, penundaan gambar, atau ketidakmampuan untuk mengakses kelas karena jaringan Internet berkecepatan rendah atau kemampuan teknis perangkat (misalnya, perangkat mungkin tidak memenuhi persyaratan minimum untuk aplikasi). Kondisi ini menimbulkan masalah baru dalam proses pembelajaran daripada mempermudah siswa.

Meskipun teknologi telah membawa kemudahan pada akses komunikasi yang menyebabkan seseorang bisa terhubung satu sama lain dari berbagai wilayah, menariknya, hubungan online ini disebut sebagai "ilusi persahabatan tanpa" persahabatan," yang dapat menjadi masalah, dan pada gilirannya, menyebabkan rasa rasa kesepian ${ }^{4}$. Dengan kata lain, hubungan yang tercipta melalui saluran online bukanlah hubungan persahabatan sesungguhnya, dan bahkan, perguruan tinggi dan universitas di Amerika dan Eropa baru-baru ini memperhatikan tren peningkatan rasa kesepian siswa dan memberikan label ini sebagai "krisis koneksi", terlebih di masa pandemic yang seluruh aktivitas pembelajaran melalui mode daring. Epidemi kesepian ini telah menjadi pembahasan khusus para peneliti dua tahun terakhir dan mendorong beberapa universitas untuk mengembangkan dan meluncurkan inisiatif yang bertujuan mendorong mahasiswa untuk menjalin koneksi yang lebih baik di kampus ${ }^{5}$.

Artikel ini bertujuan untuk mengeksplorasi berbagai potensi negatif pada pelaksanaan pembelajaran daring yang terjadi selama Pandemi COVID-19. Tanpa mengurangi manfaat besar dari teknologi yang memiliki peran sentral pada keberlangsungan pendidikan di masa pandemic, artikel ini lebih focus pada beberapa hal yang perlu diperhatikan untuk meningkatkan kualitas pembelajaran daring di masa depan.

\section{METODE PENELITIAN}

Studi ini menggunakan pendekatan literature review untuk mengesplorasi efek pembelajaran daring pada kesepian siswa. Sumber data diperoleh dari artikel yang dipublikasi dalam waktu 5 tahun terakhir, dan terutama terkait dengan pembelajaran di masa pandemic COVID19. Tinjauan pustaka diawali dengan melakukan penelusuran pustaka di Google Scholar. Artikel-

2 Alawamleh, M., Al-Twait, L. M., \& Al-Saht, G. R. (2020). The effect of online learning on communication between instructors and students during Covid-19 pandemic. Asian Education and Development Studies.

${ }^{3}$ Cahyadi, A., Hendryadi, Widyastuti, S. et al. COVID-19, emergency remote teaching evaluation: the case of Indonesia. Educ Inf Technol (2021). https://doi.org/10.1007/s10639-021-10680-3

${ }^{4}$ Turkle, S. (2010). Alone together: Why we expect more from technology and less from each other. Basic Books

5 Clay, J. (2018, December 13). USC tackles 'loneliness epidemic' in a world of social media. USCNews. https://news.usc.edu/

152830/loneliness-in-college/

Al-Madrasah: Jurnal Ilmiah Pendidikan Madrasah Ibtidaiyah

Vol. 6, No. 1, Juli-Desember 2021 
Ani Cahyadi, Agus Setiawan : Pembelajaran Daring dan Konsekuensinya Pada Kesepian Siswa : Tinjauan Literatur

artikel yang dianggap relevan berasal dari jurnal terkenal tentang e-learning yang diterbitkan oleh: Springer, Emerald, Elsevier dan Routledge.

\section{HASIL DAN PEMBAHASAN}

Mode pembelajaran daring diakui memiliki banyak manfaat bagi semua orang, terutama ketika terjadi pandemic COVID-19 dimana seluruh sekolah memindahkan proses pembelajaran tatap muka ke mode daring. Diluar kelebihannya dari sisi fleksibilitas, perlu juga mengeksplorasi berbagai kelemahannya. Kelemahan tersebut akan terbukti menjadi hambatan yang cukup besar pada kualitas pembelajaran daring itu sendiri, termasuk kualitas pendidikan di masa depan. Wong ${ }^{6}$ menggunakan kerangka evaluasi dari Ormrod (2011) menilai efektivitas pembelajaran daring berdasarkan empat kebutuhan dasar belajar adalah gairah, otonomi, keterkaitan dan kompetensi, yang digunakan sebagai kerangka teoritis untuk penelitian ini. Menggunakan metode campuran yang melibatkan 118 siswa di Hongkong menemukan bahwa kebutuhan belajar dasar otonomi dan kompetensi terpenuhi melalui pembelajaran online tetapi tidak kebutuhan keterkaitan. Otonomi ditemukan memiliki hubungan langsung dengan kompetensi tetapi tidak berhubungan atau tidak ada hubungan antara gairah dan kebutuhan belajar lainnya.

Pandemi COVID-19 telah mengakibatkan adanya isolasi sosial yang berkepanjangan yang terjadi di seluruh wilayah dunia untuk menerapkan jarak sosial untuk membatasi penularan virus. Kondisi ini menyebabkan masyarakat sepenuhnya bergantung pada teknologi digital/media sosial untuk tetap berhubungan secara social dengan kolega, teman dan keluarga. Cairns ${ }^{7}$ bersama koleganya meneliti pengalaman orang-orang terkait dengan COVID-19 dan strategi koneksi mereka selama isolasi. Studi mereka menemukan bahwa bahwa COVID-19 secara fundamental telah mengontekstualisasikan kembali hubungan antara manusia, teknologi, dan kesepian. Teknologi memiliki fungsi penuh untuk memfasilitasi hubungan antar individu selama COVID-19 terjadi. Kelas daring memberikan lebih banyak batasan pada interaksi langsung. Misalnya, asinkronisitas dan kurangnya isyarat nonverbal dapat memberikan hambatan untuk interaksi relasional.

\section{Pembelajaran daring dan perasaan kesepian pada siswa}

Setiap orang perlu merasa untuk terhubung secara sosial dengan orang lain ${ }^{8}$. Individu akan merasa kesepian ketika mereka mengalami perbedaan antara jumlah kedekatan yang diinginkan dan kepercayaan dalam hubungan sosial mereka dan hubungan mereka saat ini. Kesepian mencerminkan ancaman terhadap kebutuhan siswa dan mengungkapkan tekanan emosional mereka. Baru-baru ini, kesepian telah dianggap sebagai masalah kesehatan masyarakat yang terkait dengan peningkatan risiko masalah kesehatan mental, morbiditas, dan mortalitas9. Misalnya, perasaan kesepian secara konsisten muncul sebagai prediktor terkuat dari kesehatan mental yang buruk di kalangan mahasiswa universitas di Inggris ${ }^{10}$. Dalam studi tambahan di kalangan siswa di

${ }^{6}$ Wong, R. (2020). When no one can go to school: does online learning meet students' basic learning needs?. Interactive learning environments, 1-17.

${ }^{7}$ Cairns, M. R., Ebinger, M., Stinson, C., \& Jordan, J. (2020). COVID-19 and human connection: collaborative research on loneliness and online worlds from a socially-distanced Academy. Human Organization, 79(4), 281-291.

${ }^{8}$ Baumeister, R. F., \& Leary, M. R. (1995). The need to belong: Desire for interpersonal attachments as a fundamental human motivation. Psychological Bulletin, 117(3), 497-529

9 Cacioppo, J. T., \& Cacioppo, S. (2018). The growing problem of loneliness. The Lancet, 391(10119), 426.

${ }^{10}$ McIntyre, J. C., Worsley, J., Corcoran, R., Harrison Woods, P., \& Bentall, R. P. (2018). Academic and non-academic predictors of student psychological distress: The role of social identity and loneliness. Journal of Mental Health, 27(3), 230-239.

Al-Madrasah: Jurnal Ilmiah Pendidikan Madrasah Ibtidaiyah Vol. 6, No. 1, Juli-Desember 2021 
Ani Cahyadi, Agus Setiawan : Pembelajaran Daring dan Konsekuensinya Pada Kesepian Siswa : Tinjauan Literatur

Jerman, 35,6\% dari peserta melaporkan bahwa mereka merasa kesepian tingkat sedang sampai berat ${ }^{11}$.

Kesepian, pada gilirannya, telah ditemukan terkait dengan tingkat depresi dan kecemasan yang tinggi ${ }^{12}$. Kesepian juga merupakan prediktor negatif kinerja akademik ${ }^{13},{ }^{14}$ karena individu kurang dukungan sosial dan strategi pemecahan masalah untuk mengurangi stres akademik. Dengan demikian, kesepian dapat dianggap sebagai faktor risiko utama untuk kelelahan siswa ${ }^{15}$.

Berbagai studi baru-baru ini juga menyatakan bahwa perasaan kesepian yang terjadi pada siswa disebabkan oleh ketidakpuasan dan ketidaksenangan karena ada keterbatasan dalam berhubungan social yang dianggap tidak cukup untuk mendukung dan mengurangi kesepian dalam proses belajar mandiri ${ }^{16,17,18}$. Dalam pelaksanaannya siswa kelas daring di Amerika dan Eropa sering melaporkan bahwa perasaan kesepian ${ }^{19}$. Secara lebih spesifik, banyak siswa yang juga melaporkan kesepian sebagai penghalang untuk belajar mereka dan lebih mungkin untuk putus sekolah atau menarik diri dari kelas. Dengan demikian, kurangnya koneksi dengan teman sebaya dapat berdampak negatif pada pengalaman siswa dengan pembelajaran online. ${ }^{20}$

Selanjutnya, Conrad dan Weber ${ }^{21}$ mengingatkan guru yang menjalankan pembelajaran daring untuk menyadari bahwa aktivitas pembelajaran tidak hanya memasukkan peluang dan tugas di mana siswa berinteraksi satu sama lain, dan beberapa siswa online masih akan melaporkan perasaan kesepian dan isolasi dari rekan online mereka.

Di sisi lain, Kaufmann dan Vallade ${ }^{22}$ memfokuskan pada pengalaman pembelajaran daring siswa di Amerika Serikat juga mnemukan pembelajaran online dapat menjadi pengalaman kesepian karena kurang efektifnya kehadiran dan interaksi sosial menjadi kelemahan sekaligus upaya perbaikan untuk mengurangi rasa keseiapan siswa dalam pembelajaran daring. Mendukung

${ }^{11}$ Kaufmann, R., \& Vallade, J. I. (2020). Exploring connections in the online learning environment: student perceptions of rapport, climate, and loneliness. Interactive Learning Environments, 1-15.

12 Diehl, K., Jansen, C., Ishchanova, K., \& Hilger-Kolb, J. (2018). Loneliness at universities: determinants of emotional and social loneliness among students. International journal of environmental research and public health, 15(9), 1865.

${ }^{13}$ Fan, P. Y., Shang, Y. H., Zhu, B., Wang, J., Guo, C. T., Jin, J. Y., \& Zhang, C. X. (2021). Investigation and analysis of medical students' loneliness, learning burnout and psychological resilience under the normalization of epidemic prevention and control. China Journal of Health Psychology, 1-11.

${ }^{14}$ Yalçin, I., Özkurt, B., Özmaden, M., \& Yağmur, R. (2020). Effect of smartphone addiction on loneliness levels and academic achievement of $\mathrm{z}$ generation. International Journal of Psychology and Educational Studies, 7(1), 208-214.

${ }^{15}$ Stoliker, B. E., \& Lafreniere, K. D. (2015). The influence of perceived stress, loneliness, and learning burnout on university students' educational experience. College Student Journal, 49(1), 146-160

${ }^{16}$ Benoit, A., \& DiTommaso, E. (2020). Attachment, loneliness, and online perceived social support. Personality and Individual Differences, 167, 110230.

${ }^{17}$ Kaufmann \& Vallade loc cit

18 Yang, D., \& Swekwi, U. (2021). The Mediating Effect Of Resilience On The Relationship Between Loneliness And Academic Performance In Wuhan's College Students.

${ }^{19}$ Reedy, A. K. (2019). Rethinking online learning design to enhance the experiences of Indigenous higher education students. Australasian Journal of Educational Technology, 35(6), 132-149.

${ }^{20}$ Kaufmann \& Vallade loc cit

${ }^{21}$ Conrad, K. A., \& Weber, M. J. (2015, December). Social networking in distance learning: Planning for Success. In Academic Forum. Conference Proceedings (p. 1). The Academic Forum.

${ }^{22}$ Kaufmann \& Vallade loc cit

Al-Madrasah: Jurnal Ilmiah Pendidikan Madrasah Ibtidaiyah Vol. 6, No. 1, Juli-Desember 2021 
Ani Cahyadi, Agus Setiawan : Pembelajaran Daring dan Konsekuensinya Pada Kesepian Siswa : Tinjauan Literatur

Kaufmann dan Vallade, Laslo-Roth ${ }^{23}$ melaporkan studi serupa dengan menambahkan attention deficit disorders (ADHD) sebagai pemoderasi. Hasil studi mereka menemukan bahwa siswa dengan gangguan ADHD melaporkan tingkat kesepian yang lebih tinggi dan pengalaman yang lebih negatif dengan pembelajaran jarak jauh daripada rekan-rekan mereka. Hasil menunjukkan bahwa ADHD dan pengalaman negatif dengan pembelajaran jarak jauh memprediksi tingkat kesepian yang lebih tinggi, sementara dukungan perguruan tinggi dan dukungan teman sebaya di samping pemikiran penuh harapan memediasi hubungan ini.

Mengingat selama pandemi terjadi pemisahan melalui social distancing yang membatasi interaksi social masyakat menyebabkan terbatasnya interaksi fisik, dan kondisi ini menjadi determinan tingkat kesepian ${ }^{24}$. Studi Besser ${ }^{25}$ juga melaporkan melaporkan tingkat pengalaman yang jauh lebih tinggi dalam semua subskala kesusahan (stres, kecemasan, dan depresi) dan suasana hati negatif saat ini subskala (frustrasi, ketidakberdayaan, dan kebosanan) ketika pandemi. Selain itu, mereka melaporkan tingkat pengalaman yang jauh lebih rendah di semua subskala suasana hati positif saat ini (optimisme, kepuasan, dan kesenangan) dibandingkan dengan mereka pengalaman dalam kehidupan sehari-hari rutinitas umum.

Secara keseluruhan, Besser setuju dengan perhatian di dunia pendidikan untuk mengatasi masalah kesehatan mental dari orang-orang tidak dapat dengan mudah beradaptasi dengan keadaan mereka saat ini dan yang sedang berlangsung situasi stres. Temuan mereka juga menunjukkan perlunya mengarahkan sumber konseling kepada siswa yang memiliki kecenderungan untuk bergantung dan kritis terhadap diri sendiri.

\section{KESIMPULAN}

Artikel ini bertujuan untuk mengeksplorasi apakah pembelajaran daring memiliki potensi negative bagi siswa karena tidak efektifnya komunikasi antara pengajar dan siswa. Meskipun teknologi menawarkan banyak kemudahan dan kesempatan yang lebih besar bagi siswa untuk mengakses pembelajaran kapan saja dan dimana saja, namun sisi lainnya dapat menjadi pemicu rasa kesepian siswa karena kurangnya interaksi fisik dengan guru dan rekan sejawatnya. Suasana belajar online yang jauh dan impersonal juga dapat mendorong siswa tidak mengenal satu sama lain, dan kondisi ini kurang baik untuk perkembangan psikologis siswa.

\section{SARAN dan REKOMENDASI}

Beberapa saran dan rekomendasi berdasarkan temuan studi sebelumnya adalah: pertama, pihak sekolah perlu memastikan bahwa guru yang mengajar daring harus menerima pelatihan dalam praktik komunikasi terbaik, pedagogi, dan pengiriman konten. Ini menjadi sangat penting mengingat kompleksitas pada permasalahan teknis dan jaringan, dan situasi/kondisi siswa yang mungkin terdampak langsung pandemi. Oleh karena itu, pihak sekolah maupun pemerintah perlu membuat perencanaan menyeluruh sebelum melanjutkan pelaksanaan pembelajaran daring pasca pandemi.

Kedua, pembelajaran daring perlu direncanakan secara detail dan pihak sekolah perlu mempertimbangkan bagaimana desain kursus dan teknologi yang kemungkinan menjadi peluang

${ }^{23}$ Laslo-Roth, R., Bareket-Bojmel, L., \& Margalit, M. (2020). Loneliness experience during distance learning among college students with ADHD: the mediating role of perceived support and hope. European Journal of Special Needs Education, 1-15

${ }^{24}$ Kilgore, W. D. S., Cloonan, S. A., Taylor, E. C., \& Dailey, N. S. (2020). Loneliness: a signature mental health concern in the era of COVID-19. Psychiatry Research, 290, 1-3.

25 Besser, A., Flett, G. L., Nepon, T., \& Zeigler-Hill, V. (2020). Personality, cognition, and adaptability to the covid-19 pandemic: associations with loneliness, distress, and positive and negative mood states. International Journal of Mental Health and Addiction, 1-25.

Al-Madrasah: Jurnal Ilmiah Pendidikan Madrasah Ibtidaiyah Vol. 6, No. 1, Juli-Desember 2021 
Ani Cahyadi, Agus Setiawan : Pembelajaran Daring dan Konsekuensinya Pada Kesepian Siswa : Tinjauan Literatur

dan hambatan dalam kualitas interaksi, komunikasi, dan kolaborasi. Kelas perlu di desain dengan menciptakan kesempatan bagi siswa untuk berkomunikasi dan berkolaborasi satu sama lain untuk membangun iklim dan konektivitas yang baik antar siswa. Ketiga, guru harus dapat berkomunikasi secara positif dimana berbagai instruksi diharapkan dapat mendorong semangat dan mengurangi perasaan terisolasi dan kesepian.

\section{DAFTAR PUSTAKA}

Alawamleh, M., Al-Twait, L. M., \& Al-Saht, G. R. (2020). The effect of online learning on communication between instructors and students during Covid-19 pandemic. Asian Education and Development Studies. https://doi.org/10.1108/AEDS-06-2020-0131

Besser, A., Flett, G. L., Nepon, T., \& Zeigler-Hill, V. (2020). Personality, cognition, and adaptability to the covid-19 pandemic: associations with loneliness, distress, and positive and negative mood states. International Journal of Mental Health and Addiction, 1-25.

Baumeister, R. F., \& Leary, M. R. (1995). The need to belong: Desire for interpersonal attachments as a fundamental human motivation. Psychological Bulletin, 117(3), 497-529. https://doi.org/10.1037/0033-2909.117.3.497

Benoit, A., \& DiTommaso, E. (2020). Attachment, loneliness, and online perceived social support. Personality and Individual Differences, 167, 110230.

Cacioppo, J. T., \& Cacioppo, S. (2018). The growing problem of loneliness. The Lancet, 391(10119), 426.

Cahyadi, A., Hendryadi, Widyastuti, S. et al. COVID-19, emergency remote teaching evaluation: the case of Indonesia. Educ Inf Technol (2021). https://doi.org/10.1007/s10639-021-10680-3

Cairns, M. R., Ebinger, M., Stinson, C., \& Jordan, J. (2020). COVID-19 and human connection: collaborative research on loneliness and online worlds from a socially-distanced Academy. Human Organization, 79(4), 281-291.

Clay, J. (2018, December 13). USC tackles 'loneliness epidemic' in a world of social media. USCNews. https://news.usc.edu/152830/loneliness-in-college/

Diehl, K., Jansen, C., Ishchanova, K., \& Hilger-Kolb, J. (2018). Loneliness at universities: determinants of emotional and social loneliness among students. International journal of environmental research and public health, 15(9), 1865.

Fan, P. Y., Shang, Y. H., Zhu, B., Wang, J., Guo, C. T., Jin, J. Y., \& Zhang, C. X. (2021). Investigation and analysis of medical students' loneliness, learning burnout and psychological resilience under the normalization of epidemic prevention and control. China Journal of Health Psychology, 1-11.

Flett, G. L., \& Zangeneh,M. (2020). Mattering as a vital support for people during the COVID-19 pandemic: the benefits of feeling and knowing that someone cares during times of crisis. Journal of Concurrent Disorders, 2, 106-123.

Kaufmann, R., \& Vallade, J. I. (2020). Exploring connections in the online learning environment: student perceptions of rapport, climate, and loneliness. Interactive Learning Environments, 1-15.

Kilgore, W. D. S., Cloonan, S. A., Taylor, E. C., \& Dailey, N. S. (2020). Loneliness: a signature mental health concern in the era of COVID-19. Psychiatry Research, 290, 1-3. https://doi.org/10.1016/j.psychres.2020.113117.

Laslo-Roth, R., Bareket-Bojmel, L., \& Margalit, M. (2020). Loneliness experience during distance learning among college students with ADHD: the mediating role of perceived support and hope. European Journal of Special Needs Education, 1-15.

McIntyre, J. C., Worsley, J., Corcoran, R., Harrison Woods, P., \& Bentall, R. P. (2018). Academic and nonacademic predictors of student psychological distress: The role of social identity and loneliness. Journal of Mental Health, 27(3), 230-239.

Ormrod, J. E. (2011). Human learning (6th ed.). Pearson

Wong, R. (2020). When no one can go to school: does online learning meet students' basic learning needs? Interactive learning environments, 1-17.

Al-Madrasah: Jurnal Ilmiah Pendidikan Madrasah Ibtidaiyah Vol. 6, No. 1, Juli-Desember 2021 
Ani Cahyadi, Agus Setiawan : Pembelajaran Daring dan Konsekuensinya Pada Kesepian Siswa : Tinjauan Literatur

Reedy, A. K. (2019). Rethinking online learning design to enhance the experiences of Indigenous higher education students. Australasian Journal of Educational Technology, 35(6), 132-149.

Spadafora, N., \& Volk, A. A. (2021). Child and Youth Classroom Incivility Scale (CYCIS): exploring uncivil behaviors in the classroom. School mental health, 13(1), 186-200.

Stoliker, B. E., \& Lafreniere, K. D. (2015). The influence of perceived stress, loneliness, and learning burnout on university students' educational experience. College Student Journal, 49(1), 146-160

Yalçin, I., Özkurt, B., Özmaden, M., \& Yağmur, R. (2020). Effect of smartphone addiction on loneliness levels and academic achievement of z generation. International Journal of Psychology and Educational Studies, 7(1), 208-214.

Yang, D., \& Swekwi, U. (2021). The Mediating Effect Of Resilience On The Relationship Between Loneliness And Academic Performance In Wuhan's College Students.

Al-Madrasah: Jurnal Ilmiah Pendidikan Madrasah Ibtidaiyah

Vol. 6, No. 1, Juli-Desember 2021 